\title{
The United States Department of Agriculture policies to improve school food quality while protecting the environment
}

\author{
S. Wunderlich, Y. Bai \& S. Chung \\ Department of Health and Nutrition Sciences, \\ Montclair State University, USA
}

\begin{abstract}
In the United States, the Farm Bill is the primary agriculture and food policy legislation and its administration is under the preview of the United States Department of Agriculture (USDA). The USDA has established policies and programs aimed at providing school children with better food and at the same time, supporting local farmers. The Farm to School Program connects schools and local farms with the objectives of serving healthy meals in school and supporting local and regional farmers. It is believed that local and regional farmers are deeply committed to social and environmental concerns. The Farm to School Program is now operational in more than 10,000 schools spanning all 50 states. In 2008, the Farm Bill allowed food service directors to give preference to local products. The Fresh Fruit and Vegetable Program (FFVP) combats childhood obesity by helping children learn more healthful eating habits. The current study examines this program in a selected school to evaluate the program implementation and variables that can improve the success of the program. Students, teachers, and parents have generally received the FFVP program very well and most stated that the students highly enjoy the program. The selection of fruits and vegetables to be offered depended on the budget as well as the food popularity, which limited offering of culturally salient fruits and vegetables. A better education strategy is needed to promote vegetable intake to achieve the full potential value of the program. Increased consumption of fresh fruits and vegetables from local farmers leads to a reduction in food transportation distance, which directly reduces environmental impact.

Keywords: farm bill, farm to school, fresh fruit and vegetable program.
\end{abstract}




\section{Introduction}

The United States is one of the largest and most industrialized nations in the world. Its large scale food production methods have very high yields but can also have a negative impact on the environment. Large-scale food production is largely dependent on fossil fuels, contributing to global warming because of the greenhouse gases that are emitted during food production and transport. Food in the United States has been transported an average of 1,518 miles (about 2,400 kilometers) from large farms to consumers. The locally produced food, however, traveled an average of just 44.6 miles (72 kilometers) (Leopold [1]). The results of other studies, [2, 3], have shown that obesity among Americans is also increasing at an alarming rate. One way to combat this is to encourage consumers to consume more plant based foods that are produced locally. Local farms can have much less of a negative impact on the environment and can produce fresher, healthier foods for people to lead healthier lives (Francis and Porter [4]). Several US government programs are targeting these issues.

The 2012 Farm Bill would greatly contribute to the growth of local agriculture as there would be more secure funding for agriculture research, an expansion of local and regional farm markets, and an increase in economic opportunities for local farmers. In addition, the 2012 Farm Bill would make fruits, vegetables, and whole grains comparatively less expensive than unhealthy processed foods and meats, enabling consumers to make good nutritional choices (Foster [5]). The Farm Bill is under the preview of the United States Department of Agriculture (USDA) and the USDA has established policies and programs supporting local farmers and helping provide school children with better food. The Farm to School and Fresh Fruit and Vegetable Program are programs aiming to combat childhood obesity by helping students develop healthier eating habits. Farm to School programs promote schools to buy local foods and contribute to children choosing more fruits and vegetables (Tucker $[6,7])$. The Fresh Fruit and Vegetable Program (FFVP) creates a healthier school environment by expanding the opportunities for children to sample varieties of fruits and vegetables. Both programs are very beneficial in addressing the national health crisis of increasing obesity.

Programs such as the Fresh Fruit and Vegetable Program and Farm to School programs encourage schools to buy food locally from local farmers, leading to a mutually beneficial situation. The local farmers benefit by finding the markets, such as schools, for their products and the entire nation benefits by protecting the environment through the practice of local agriculture. A sample study was conducted to examine the FFVP in a selected school to evaluate the program implementation and to determine variables that can improve the success of the program. 


\section{Methodology}

\subsection{Study site}

An observational study was conducted in a New Jersey public elementary school that received the governmental funding to implement the Fresh Fruit and Vegetable Program (FFVP). The purpose of the study was to evaluate implementation of the FFVP at this sample school.

\subsection{Sample population}

The FFVP snack preparation, delivery, consumption by children, and nutrition education sessions were observed and recorded. Program stakeholders, such as the FFVP coordinator, principals, teachers, school nutrition staff, and parents participated in the study. Surveys and interviews were used to explore facilitators and challenges of FFVP implementation. Interview responses were transcribed and coded to extract common concepts using thematic content analysis. Descriptive analyses were conducted on the participant demography and survey responses.

\section{Results}

One hundred thirty four $(n=134)$ parents, and 37 stakeholders $(n=37)$ were recruited for interviews and completing the surveys. Stakeholders included the FFVP coordinator, teachers, school nutrition director, and school administrators. The demography of study participants is shown in Table 1.

\subsection{Fruit and vegetables samples}

The FFVP coordinator was responsible for organizing the program and ordering the food. Seasonal fresh fruits and vegetables were ordered from a national food distributor in whole or pre-cut forms. They were given to the students as prepared snacks. The delivery of the snacks in all grades (K-5) was observed. In $92 \%$ of the observations conducted, no specific nutrition education, or healthy eating discussion regarding the snacks that were served, occurred during the snack time. From the observation of weekly nutrition education sessions, researchers noted that topics discussed in the session were not aligned with the fruit or vegetable served that week.

\subsection{Interviews with stakeholders}

A total of 37 stakeholders were interviewed: 31 teachers, 3 staff members (the principal, vice principal, and program coordinator), and 3 volunteers. Stakeholders perceived that program implementation was successful, which they described as "running smoothly," "good," or "well-coordinated and effective." 
Table 1: $\quad$ Demography of study participants.

\begin{tabular}{|c|c|c|c|}
\hline Characteristics & $\begin{array}{l}\text { Stakeholders(n=37) } \\
\text { Number }(\%)\end{array}$ & $\begin{array}{l}\text { Teachers }(\mathrm{n}=31) \\
\text { Number }(\%)\end{array}$ & $\begin{array}{c}\text { Parents } \\
(\mathrm{n}=134) \\
\text { Number }(\%)\end{array}$ \\
\hline \multicolumn{4}{|c|}{ Race } \\
\hline Asian & $2(5.4)$ & $2(6.5)$ & $4(2.9)$ \\
\hline Non-Hispanic Black & $0(0)$ & $0(0)$ & $5(3.7)$ \\
\hline Latino & $3(8.1)$ & $3(9.7)$ & $86(64.1)$ \\
\hline Non-Hispanic White & $31(83.7)$ & $25(80.6)$ & $23(17.1)$ \\
\hline Others & $1(2.7)$ & $1(3.2)$ & $14(10.4)$ \\
\hline No response & $0(0)$ & $0(0)$ & $2(1.4)$ \\
\hline \multicolumn{4}{|c|}{ Education } \\
\hline Below high school & $0(0)$ & $0(0)$ & $27(20.1)$ \\
\hline High school & $3(8.1)$ & $0(0)$ & $54(40.2)$ \\
\hline Some college & $0(0)$ & $0(0)$ & $14(10.4)$ \\
\hline College graduate & $22(59.4)$ & $21(67.7)$ & $29(21.6)$ \\
\hline Post college & & $10(32.3)$ & $0(0)$ \\
\hline No response & & $0(0)$ & $10(7.4)$ \\
\hline Home Room & N/A & & N/A \\
\hline $\mathrm{K}$ & & $6(19.4)$ & \\
\hline $1 \mathrm{st}$ & & $6(19.4)$ & \\
\hline 2nd & & $4(12.9)$ & \\
\hline 3rd & & $4(12.9)$ & \\
\hline 4th & & $5(16.1)$ & \\
\hline 5th & & $5(16.1)$ & \\
\hline Special Education & & $1(3.2)$ & \\
\hline Age (Mean \pm SD), years & $46 \pm 1.7$ & $43.7 \pm 14.4$ & $34.3 \pm 8.4$ \\
\hline
\end{tabular}

Some stakeholders (60\%) expressed concern regarding the school's ability to deliver the FFVP (see Figure 1). Most of the stakeholders indicated that the timing (morning vs. afternoon) of the snack delivery was important for the success of the program. When the snacks were delivered in the afternoon, the children rushed to eat the snack or would take it home with them. Some stakeholders indicated that types of snacks served were important for efficient delivery. For example, serving easily cut-up fruits and vegetables such as apples or carrots required less labor than serving items (e.g. cantaloupes) that required seeding, sectioning, and portioning into serving cups.

Some challenges were mentioned by $60 \%$ of interviewees; the remaining stated they were satisfied with the implementation procedure.

The USDA requires that FFVP snacks be served only during the school day, and not before or after school. Teachers commented that teacher's supervision would assist in ensuring that children consume foods offered, supporting a morning snack delivery time. 


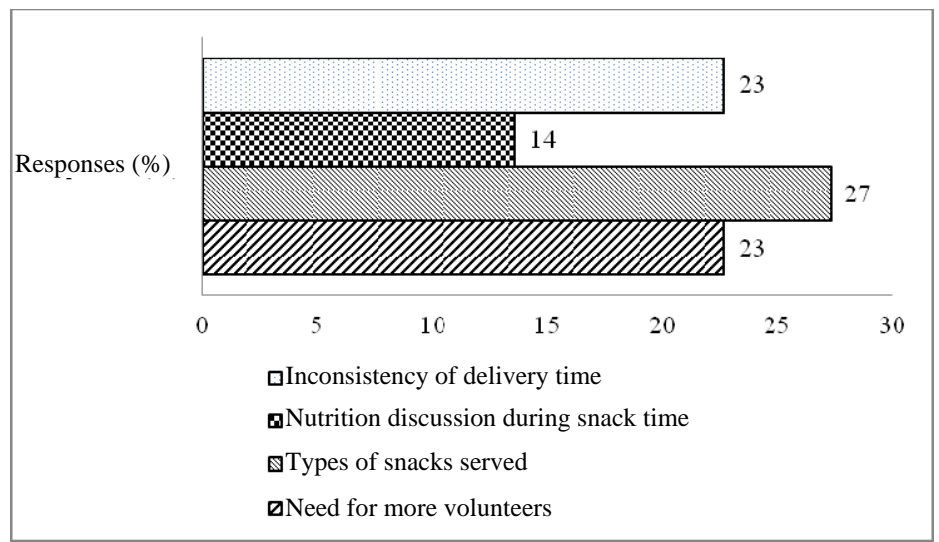

Figure 1: Frequently mentioned challenges faced during the program implementation. Graph shown is the percent representation of common responses by stakeholder interviewees.

\subsection{Teacher and parent surveys}

Modal responses of teachers to question items are shown in Table 2. A majority of the teachers (82\%) rated the implementation of the FFVP as very good. Student's enjoyment of the program was also rated high by $71 \%$ of teachers.

Table 2: $\quad$ Teacher survey responses.

\begin{tabular}{|l|c|c|}
\hline Questionnaire Items & Modal responses & $\begin{array}{c}\text { Percent } \\
\text { responses }\end{array}$ \\
\hline How do you rate the FFVP implementation? & Very good & 82 \\
\hline $\begin{array}{l}\text { Educational sessions to teach about FFVP } \\
\text { were... }\end{array}$ & Fully implemented & 53 \\
\hline $\begin{array}{l}\text { In your opinion, the level of students’ enjoyment } \\
\text { of the FFVP was... }\end{array}$ & High & 71 \\
\hline $\begin{array}{l}\text { In your opinion, how many newsletters were } \\
\text { handed to students to take home? }\end{array}$ & Some & 30 \\
\hline $\begin{array}{l}\text { In your opinion, how many newsletters were read } \\
\text { by parents? }\end{array}$ & All & 71 \\
\hline $\begin{array}{l}\text { In your opinion, FFVP promotion during Home } \\
\text { and School Association monthly meeting } \\
\text { happened... }\end{array}$ & None & 31 \\
\hline $\begin{array}{l}\text { In your opinion, the snack information was } \\
\text { included in monthly menu calendar }\end{array}$ & None visible & 47 \\
\hline In your opinion, posters were made in art class... & & 56 \\
\hline $\begin{array}{l}\text { In your opinion, posters were displayed } \\
\text { throughout the school... }\end{array}$ & & 30 \\
\hline
\end{tabular}


However, specific promotional activities were somewhat less recognized by the teachers; more than $50 \%$ of them responded never made or none visible when asked about promotional posters. Responses were similar between homeroom teachers $(p>0.05)$. The promotional activities to increase the awareness and create the excitement about the program were encouraged by the USDA, but not required.

Of those who responded to the open-ended question inquiring about strategies employed to encourage children's fruit and vegetable consumption, 53\% of the teachers indicated that they discussed "benefits of eating fruits and vegetables," "nutritional values of fruits and vegetables," or "healthy food choices throughout the year." Teachers also stated that they provided encouragement during snack distribution time; $20 \%$ of teachers reported they reinforced the importance of fruit and vegetable consumption (e.g., discussing the specific fruit or vegetable being served), and $13.3 \%$ of teachers responded that they served as a role model by tasting the snacks with students.

Although the program was ongoing throughout the school year, $16 \%$ of parents still indicated that they were "not at all familiar" with the program. Parent observations of children's enjoyment of the FFVP were highly positive. For example, parents reported that their child "liked the snacks a lot," and that the "perception of FFVP was very good." Responses were similar regardless of parent's race and education levels ( $\mathrm{p}>0.05)$.

These types of programs help not only to improve healthy eating among children, they provide steady markets for the local farmers to sell their products and encourage caring for the environment.

\section{Conclusions}

These findings suggest that the operation of the FFVP in this school was generally perceived to be successful by program staff, teachers, and parents. The level of students' satisfaction was highly positive, as noted by parents. The excitement observed by the researchers during the snack time supported the level of students' satisfaction as measured by the questionnaire. Better coordination with nutrition education could enhance the program operation, thus having a stronger impact on the students. Strategic promotional activities need to be employed to increase parents' interest and engagement in the program. Eating behavior is a function of the varied food environments that are composed of individual food preference, cultural and familial influences, and home, school and community environments (Haire-Joshu and Nanney [8]). The FFVP has a great potential to impact the eating behavior of school age children by shaping each child's food preference via healthy food offerings at school. Children's healthy eating habits learned from school at an early age could have a dynamic impact on their homes and communities and most importantly, on their health. This evaluation study allowed researchers to assess the implementation of the FFVP, identify concerns of the operation, suggest solutions to improve the program, and suggest alternate methods of snack delivery, such as fruit and vegetable vending machines or mobile carts. The findings are valuable in 
increasing success rates for subsequent programs. Finally, continuous funding support is necessary to nurture this important program so that schools may sustain and enhance an environment conducive to healthy eating, and ultimately improve children's and the nation's health. At the same time, programs such as the FFVP can sustain small farmers and therefore reduce negative environmental impacts. The policies regarding the government food programs in the future should accentuate the importance of protection of the environment.

\section{References}

[1] Leopold Center for Sustainable Agriculture Iowa Local Food \& Farm Plan 2011.

[2] Berners-Lee, M., Hoolohan, C., Cammack, H., and Hewitt, C. (2012). The relative greenhouse gas impacts of realistic dietary choices. Energy Policy, 43, 184-190.

[3] Roy, P., Orikasa, T., Thammawong, M., Nakamura, N., Xu, Q., and Shiina, T. (2012). Life cycle of meats: An opportunity to abate the greenhouse gas emission from meat industry in Japan. Journal of Environmental Management, 93(1), 218-224.

[4] Francis, C., and Porter, P. (2011). Ecology in sustainable agriculture practices and systems. Critical Reviews in Plant Sciences, 30(1), 64-73.

[5] Foster, J. (2011). Subsidizing fat: How the 2012 Farm Bill can address America's obesity epidemic. University of Pennsylvania Law Review, 160(1), 235-276.

[6] Tucker, C. (2011). Farm-to-school program encourages Oregon districts to buy local foods. Nation's Health, 41(7), 11-11.

[7] Tucker, C. (2012). When your board builds the chicken coop. Independent school, 71(3), 10-10.

[8] Haire-Joshu, D., and Nanney, M. S. (2002). Prevention of overweight and obesity in children: Influences on the food environment. The Diabetes Educator, 28 (3), 415-423.

[9] Bai, Y., Feldman, C., Wunderlich, S. M., and Aletras, S. C. (2011) Process evaluation of the fresh fruit and vegetable program implementation in New Jersey elementary school. Journal of Child Nutrition \& Management, 35 (2), 9 pages. Retrieved from http://www.schoolnutrition.org/Content. aspx?id=16319

[10] Azadi, H., Schoonbeek, S., Mahmoudi, H., Derudder, B., Maeyer, P. D., and Witlox, F. (2011). Organic agriculture and sustainable food production system: Main potentials. Agriculture, Ecosystems \& Environment, 144(1), 92-94.

[11] Bjorklund, J., Westberg, L., Geber, U., Milestad, R., and Ahnstrom, J. (2009). Local selling as a driving force for increased on-farm biodiversity. Journal of Sustainable Agriculture, 33, 885-902.

[12] Vanek, F., and Sun, Y. (2008). Transportation versus perishability in life cycle energy consumption: A case study of the temperature-controlled food product supply chain. Transportation Research Part D, 13, 383-391. 